\title{
Screening and Enzymatic Study of a Composite Microbial System FH3
}

\author{
Yi-Min Zhang ${ }^{1 *}$, Xue-Bin Lu ${ }^{1}$, Han-Bin Dan ${ }^{2}$ and Ya-Kai Sun ${ }^{1}$ \\ ${ }^{I}$ Key Laboratory of Green Chemical Technology; School of Chemical Engineering and Technology; Tianjin \\ University; Tianjin 300072; China. ${ }^{2}$ Department of Biological Sciences Lehman College; City University of New \\ York; NY 10468; USA
}

\begin{abstract}
Five strains of fungi and 18 strains of bacteria were isolated from the soil and horse manure with cellulose as the sole carbon source. Among them, two fungal, $F_{9}$ and $F_{13}$, and two bacterial, $B_{16}$ and $B_{21}$, showed the highest filter paper activities, which were $7.79 \mathrm{U} \mathrm{g}^{-1}, 9.84 \mathrm{U} \mathrm{g}^{-1}, 7.34 \mathrm{U} \mathrm{g}^{-1}$ and $9.68 \mathrm{U} \mathrm{g}^{-1}$, respectively. Four microbial systems, designed as FH1 $\left(F_{13}+B_{21}\right)$, FH2 $\left(F_{13}+B_{16}+B_{21}\right)$, FH3 $\left(F_{9}+B_{16}+B_{21}\right)$ and FH4 $\left(F_{13}+F_{9}+B_{16}+B_{21}\right)$ were developed. The fermentation studies showed that the filter paper activity of the composite microbial system FH3 was higher than the others, which was $21.34 \mathrm{U} \mathrm{g}^{-1}$. The medium with bran and filter paper as the carbon source and peptone as nitrogen source was optimal and the maximum cellulase activity was reached at $30 \sim 35^{\circ} \mathrm{C}$ and $\mathrm{pH} 6.0 \sim 6.5$ when $\mathrm{FH} 3$ was incubated for $48 \mathrm{~h}$. The enzymatic reaction conditions were estimated at $45 \sim 55^{\circ} \mathrm{C}, \mathrm{pH} 4.5 \sim 5.5$ and the thermal stability temperature was up to $60^{\circ} \mathrm{C}$.
\end{abstract}

Key words: Cellulose-degrading bacterium, composite microbial systems, enzyme properties

\section{INTRODUCTION}

Cellulose is the major carbohydrate polymeric compound in the plants and is the most abundant organic compound on the earth. Accordingly, its turnover in the carbon cycle is of prime importance for all the living organisms (Peter et al., 1999; Garsoux et al., 2004). Huge amounts of the cellulosic wastes, measured in billions of tons annually, are produced worldwide as the residues from the agriculture activities and industrial food processing. In China, crop straw waste exceeds 100 million tons per year (Haruta et al., 2004). The enormous potential of cellulose as a renewable source of energy was recognized only after the cellulose degrading enzymes or cellulases had been identified (Mandels, 1985). Cellulases are enzymes that hydrolyse $\beta$-1, 4-glycosidic bonds in cellulose, releasing cellobiose as the smallest product. These enzymes can be found associated with the cellulosome, an extracellular supramolecular assembly produced by some bacteria and fungi (Shoham et al., 1999; Carrard et al., 2000), but are generally secreted as independent enzymes by the cellulolytic microorganisms. Efforts have been directed to find the suitable cellulase-producing micro-organisms through the strain selection and development. Trichoderma reesei has been studied extensively because of its ability to produce a good cellulose

\footnotetext{
* Author for correspondence
} 
enzyme complex that is capable of hydrolysing cellulose. However it produces little cellobiase and xylanase activities, which is a disadvantage from the point of practical saccharification. Kang et al (1994) found that Aspergillus niger was a more promising strain than Trichoderma reesei (Kim et al., 1997). Van Wyk et al (2003) treated various wastepaper materials with the cellulase from viride and converted their cellulose component into fermentation sugars. In nature, the cellulose materials are degraded with mixed group of the microorganisms. It has been reported that a mixed culture of one cellulolytic bacterium together with another noncellulolytic bacterium is ideal for degrading the cellulose. As such, the utilization of a complex microbial community could be effective in achieving the high degradation efficiency for natural cellulosic materials.

In the present study, a composite microbial system FH3 was constructed, which had a higher enzyme activity than any of the separate composting strains. The conditions for the rapid and high cellulase production by the FH3 are described. Some of the properties of the enzyme consortium are also presented.

\section{MATERIALS AND METHODS}

\section{Experimental materials}

The soil and horse faeces were collected from the cornfield and meadow of Tianjin suburb (Tianjin, China). Xinhua mensurable filter paper was cut into pieces $(6 \mathrm{~cm}$ in length and $1 \mathrm{~cm}$ in width). Cellulose-congo red medium was composed of $0.50 \mathrm{~g} \mathrm{~K}_{2} \mathrm{HPO}_{4}, 0.25 \mathrm{~g} \quad \mathrm{MgSO}_{4}, 1.88 \mathrm{~g}$ cellulose powder, $0.20 \mathrm{~g}$ congo red, $14.00 \mathrm{~g}$ agar, $2.00 \mathrm{~g}$ glutin, $100 \mathrm{~mL}$ soil solution and $900 \mathrm{~mL} \mathrm{H}_{2} \mathrm{O}$, pH7.0. The liquid fermentation medium 1 (bacterial) was composed of $1.00 \mathrm{~g} \mathrm{KH}_{2} \mathrm{PO}_{4}, 0.10 \mathrm{~g}$ $\mathrm{NaCl}, 2.50 \mathrm{~g} \mathrm{NaNO}_{3}, 0.30 \mathrm{~g} \mathrm{MgSO}_{4}, 0.01 \mathrm{~g} \mathrm{FeCl}_{3}$, $0.10 \mathrm{~g} \mathrm{CaCl}_{2}, 10 \mathrm{~g}$ bran and $1000 \mathrm{~mL} \mathrm{H}_{2} \mathrm{O}, \mathrm{pH} 7.2$. The liquid fermentation medium 2 (fungal) was composed of $3.00 \mathrm{~g}$ peptone, $2.00 \mathrm{~g}\left(\mathrm{NH}_{4}\right)_{2} \mathrm{SO}$, $0.50 \mathrm{~g}$ yeast extract, $4.00 \mathrm{~g} \mathrm{KH}_{2} \mathrm{PO}_{4}, 0.30 \mathrm{~g} \mathrm{CaCl}_{2}$, $0.30 \mathrm{~g} \mathrm{MgSO}_{4}, 0.20 \mathrm{~g}$ Tween-80, $10 \mathrm{~g}$ bran and $1000 \mathrm{~mL} \mathrm{H}_{2} \mathrm{O}, \mathrm{pH}$ 6.0. The peptone cellulose substrate (PCS) was composed of $1.00 \mathrm{~g}$ yeast extract, $5.00 \mathrm{~g}$ peptone, $2.00 \mathrm{~g} \mathrm{CaCO}_{3}, 5.00 \mathrm{~g} \mathrm{NaCl}$, $20.00 \mathrm{~g}$ cellulosic materials and $1000 \mathrm{~mL} \mathrm{H}_{2} \mathrm{O}$.

\section{Screening for cellulose decomposing microbial strains}

Different sample solutions were spread on the cellulose-congo red plates and incubated at $30^{\circ} \mathrm{C}$ for $72 \mathrm{~h}$. The purified strains were obtained and inoculated on the cellulose-congo red medium and cultured at $30{ }^{\circ} \mathrm{C}$ for six days. The strains were selected according to the value of $\mathrm{H} / \mathrm{C}$ (Table 1). After that, one milliliter suspension of these strains was inoculated in the liquid medium 1 or 2 and cultured at $30^{\circ} \mathrm{C}$ for three days. By measuring the enzyme activity, some strains were chosen for the next combination experiment.

\section{Strain combinations}

Four composite microbial systems were developed according to their cellulose-degrading enzyme activities. One milliliter suspension of the four composite microbial systems was inoculated in the PCS liquid medium and incubated at $30{ }^{\circ} \mathrm{C}$ for three days. The desired composite microbial systems were selected by its three enzyme activities and were used in the fermentation experiment.

\section{Enzyme assays}

The cellulase activities were measured by DNS (3, 5-dinitrosalicylic acid) assay (Miller, 1959), through the determination of the amount of reducing sugars from filter paper, $\mathrm{CMC}$ and cotton. The three reactions were performed under different experimental conditions (temperature: 50 ${ }^{\circ} \mathrm{C}, 45^{\circ} \mathrm{C}$ and $45^{\circ} \mathrm{C}$; time: $1 \mathrm{~h}, 0.5 \mathrm{~h}$ and $24 \mathrm{~h}$ ) and stopped by the addition of the DNS solution. The treated samples were boiled in the capped glass tubes for $10 \mathrm{~min}$, cooled in the water for color stabilization and the optical density was measured at $\mathrm{A}_{540}$. The cellulase activities were determined from a calibration curve for glucose $\left(\varepsilon_{540}=3.2 \times 10^{2}\right.$ $\left.\mathrm{L} \cdot \mathrm{mol}^{-1} \cdot \mathrm{cm}^{-1}\right)$. One unit (U) of the enzyme activity was defined as the amount of enzyme that released $1 \mu \mathrm{mol}$ of reducing sugar per minute under the assay conditions. All the enzymatic assays were performed in triplicate.

\section{RESULTS AND DISCUSSIONS}

\section{Strains screening}

Twenty-three strains of cellulose-degrading 
bacteria were isolated from the soil and horse feces. Eight strains were finally chosen for further study according to the diameter of the hydrolysis zones. Among them, $\mathrm{F}_{9}$ and $\mathrm{F}_{13}$ were fungi, while the others were bacteria (Table 1).

Table 1-The status of H, C, and H/C of the eight strains over six days.

\begin{tabular}{cccccccccc}
\hline \multirow{2}{*}{ Strains } & \multicolumn{3}{c}{ Time (2d) } & \multicolumn{3}{c}{ Time (4d) } & \multicolumn{3}{c}{ Time (6d) } \\
\cline { 2 - 10 } & \multirow{2}{*}{$\mathbf{H} / \mathbf{c m}$} & $\mathbf{C} / \mathbf{c m}$ & $\mathbf{H} / \mathbf{C}$ & $\mathbf{H} / \mathbf{c m}$ & $\mathbf{C} / \mathbf{c m}$ & $\mathbf{H} / \mathbf{C}$ & $\mathbf{H} / \mathbf{c m}$ & $\mathbf{C} / \mathbf{c m}$ & $\mathbf{H} / \mathbf{C}$ \\
\hline $\mathrm{B}_{4}$ & $0.70 \pm 0.02$ & $0.40 \pm 0.01$ & $1.75 \pm 0.10$ & $1.00 \pm 0.01$ & $0.50 \pm 0.01$ & $2.00 \pm 0.06$ & $1.20 \pm 0.01$ & $0.60 \pm 0.01$ & $2.00 \pm 0.05$ \\
$\mathrm{~F}_{9}$ & $1.25 \pm 0.02$ & $0.70 \pm 0.01$ & $1.79 \pm 0.06$ & $3.10 \pm 0.02$ & $1.00 \pm 0.01$ & $3.10 \pm 0.05$ & $4.80 \pm 0.02$ & $1.50 \pm 0.01$ & $3.20 \pm 0.03$ \\
$\mathrm{~B}_{12}$ & - & - & - & $1.10 \pm 0.01$ & $0.50 \pm 0.01$ & $2.20 \pm 0.07$ & $1.40 \pm 0.01$ & $0.85 \pm 0.01$ & $1.65 \pm 0.03$ \\
$\mathrm{~F}_{13}$ & $1.50 \pm 0.01$ & $0.80 \pm 0.01$ & $1.88 \pm 0.04$ & $3.60 \pm 0.02$ & $1.00 \pm 0.01$ & $3.60 \pm 0.06$ & $4.90 \pm 0.02$ & $1.20 \pm 0.01$ & $4.08 \pm 0.05$ \\
$\mathrm{~B}_{15}$ & $1.00 \pm 0.01$ & $0.60 \pm 0.01$ & $1.67 \pm 0.05$ & $1.20 \pm 0.01$ & $0.90 \pm 0.01$ & $1.33 \pm 0.03$ & $1.25 \pm 0.01$ & $1.00 \pm 0.01$ & $1.25 \pm 0.02$ \\
$\mathrm{~B}_{16}$ & $2.50 \pm 0.02$ & $0.80 \pm 0.01$ & $3.13 \pm 0.06$ & $2.80 \pm 0.01$ & $0.85 \pm 0.01$ & $3.29 \pm 0.05$ & $3.00 \pm 0.02$ & $0.95 \pm 0.01$ & $3.16 \pm 0.05$ \\
$\mathrm{~B}_{17}$ & - & - & - & $0.60 \pm 0.01$ & $0.40 \pm 0.01$ & $1.50 \pm 0.06$ & $2.10 \pm 0.01$ & $0.60 \pm 0.01$ & $3.50 \pm 0.08$ \\
$\mathrm{~B}_{21}$ & $1.50 \pm 0.01$ & $0.60 \pm 0.01$ & $2.50 \pm 0.06$ & $2.10 \pm 0.02$ & $1.00 \pm 0.01$ & $2.10 \pm 0.04$ & $3.80 \pm 0.01$ & $1.20 \pm 0.01$ & $3.17 \pm 0.04$ \\
\hline
\end{tabular}

*H: the diameter of hydrolysis zone, $\mathrm{C}$ : the diameter of colony, $\mathrm{H} / \mathrm{C}$ : the ratio of $\mathrm{H}$ and $\mathrm{C}$.

$\mathrm{F}_{9}, \mathrm{~F}_{13}, \mathrm{~B}_{16}$ and $\mathrm{B}_{21}$ had a higher ability of cellulose degrading than the other strains. $\mathrm{F}_{9}$ and $F_{13}$ were two strains of fungi and their diameter of the hydrolysis zones developed quickly with the diversification of the diameter colony. On the sixth day, the $\mathrm{H} / \mathrm{C}$ value of $\mathrm{F}_{9}$ reached 3.2 , while $\mathrm{F}_{13}$ reached 4.08. In the screening process, the $\mathrm{H} / \mathrm{C}$ values of $B_{16}$ and $B_{21}$ also reached 3.0. Though the $\mathrm{H} / \mathrm{C}$ value of $\mathrm{B}_{17}$ reached 3.5 , its hydrolytic zone and colony was very low. $\mathrm{B}_{17}$ grew slowly and had a poor ability on cellulose decomposing.

\section{Enzyme activity measuring}

One-milliliter bacterial suspension of $\mathrm{B}_{4}, \mathrm{~B}_{12}, \mathrm{~B}_{15}$, $\mathrm{B}_{16}, \mathrm{~B}_{17}$ and $\mathrm{B}_{21}$ was inoculated in $50 \mathrm{~mL}$ liquid fermentation medium 1. The suspension of $F_{9}$ and $\mathrm{F}_{13}$ was inoculated in liquid fermentation medium 2 in the same quantity. They were incubated at 30 ${ }^{\circ} \mathrm{C}$ at $160 \mathrm{rpm}$ for three days. The results of enzyme activities are shown in Table 2.

Table 2 - Enzyme activities of different strains.

\begin{tabular}{cccc}
\hline \multirow{2}{*}{ Strain Nos } & \multicolumn{3}{c}{ Cellulase activities } \\
\cline { 2 - 4 } & $\begin{array}{c}\text { filter paper } \\
\left(\mathbf{U} \mathbf{~ g}^{-\mathbf{1}}\right)\end{array}$ & $\begin{array}{c}\mathbf{C M C} \\
\left(\mathbf{U} \mathbf{g}^{-\mathbf{1}}\right)\end{array}$ & $\begin{array}{c}\text { Cotton } \\
\left(\mathbf{U} \mathbf{~ g}^{\mathbf{- 1}}\right)\end{array}$ \\
\hline $\mathrm{B}_{4}$ & $3.05 \pm 0.12$ & $10.22 \pm 0.61$ & $0.32 \pm 0.02$ \\
$\mathrm{~F}_{9}$ & $7.79 \pm 0.43$ & $23.66 \pm 0.96$ & $0.30 \pm 0.02$ \\
$\mathrm{~B}_{12}$ & $1.17 \pm 0.08$ & $9.68 \pm 0.48$ & $0.18 \pm 0.01$ \\
$\mathrm{~F}_{13}$ & $9.84 \pm 0.49$ & $27.78 \pm 1.02$ & $0.51 \pm 0.03$ \\
$\mathrm{~B}_{15}$ & $3.41 \pm 0.17$ & $28.86 \pm 1.05$ & $0.56 \pm 0.03$ \\
$\mathrm{~B}_{16}$ & $7.34 \pm 0.37$ & $39.53 \pm 1.23$ & $0.56 \pm 0.03$ \\
$\mathrm{~B}_{17}$ & $3.81 \pm 0.19$ & $6.09 \pm 0.30$ & $0.38 \pm 0.02$ \\
$\mathrm{~B}_{21}$ & $9.68 \pm 0.58$ & $60.05 \pm 1.60$ & $0.65 \pm 0.04$ \\
\hline
\end{tabular}

Table 2 showed that all the strains of bacteria and fungi presented filter paper activity, and the largest values were obtained for $F_{13}$ and $B_{21}$ and the smallest value for the strain $B_{12}$. Strain $B_{21}$ had the largest value for CMCase, and $B_{17}$ had the smallest. Strain $\mathrm{B}_{21}$ had the largest value for cotton activity, and $\mathrm{B}_{12}$ had the smallest. Considering the three activities, the strains $\mathrm{B}_{4}, \mathrm{~B}_{12}$ and $\mathrm{B}_{17}$ presented smaller values in relation to the other strains. Therefore, strain $\mathrm{B}_{21}$ was the best for CMCase and cotton activities. In this study, strain's isolation was based on the filter paper enzyme activity. As cellulose material has moderate degree of polymerization and crystallization, filter paper could be used as a substitute for the natural cellulose (Li et al., 2003). 
Therefore, the filter paper enzyme activity could reflect the cooperative action of three cellulases, and regarded as the basis of strain isolation. Among the eight strains of the cellulose-degrading microorganisms, $\mathrm{F}_{9}, \mathrm{~F}_{13}, \mathrm{~B}_{16}$ and $\mathrm{B}_{21}$ showed the higher filter paper enzyme activities, which were 7.79, 9.84, 7.34 and $9.68 \mathrm{U}$ g-1, respectively. It proved that $F_{9}, F_{13}, B_{16}$ and $B_{21}$ had the highest cellulose-degrading ability. The result was consistent with $\mathrm{H} / \mathrm{C}$ value.

\section{Strain combinations}

Strains $F_{13}$ and $B_{21}$, which had the highest filter paper enzyme activity, were combined to form the composite microbial system FH1. Strains $F_{13}$ with the highest filter paper enzyme activity, $\mathrm{B}_{21}$ with the highest CMC enzyme activity and $\mathrm{B}_{16}$ with the highest cotton enzyme activity were combined to form the composite microbial system FH2. Strains $\mathrm{F}_{9}$ with a high filter paper enzyme activity, $\mathrm{B}_{21}$ with the highest CMC enzyme activity and $\mathrm{B}_{16}$ with the highest cotton enzyme activity were combined to form the composite microbial system FH3. All the four strains were combined to form the composite microbial system FH4. The four composite microbial systems were inoculated in the PCS liquid medium and incubated at $30{ }^{\circ} \mathrm{C}$ and $160 \mathrm{rpm}$ for three days. The crude enzyme activities were measured and results are shown in Table 3. Table 3 indicated that the filter paper activity of the composite microbial system FH1 was $11.13 \mathrm{U} \mathrm{g}-1$ with an increase of $13.1 \%$ and $15.0 \%$ compared to $\mathrm{F}_{13}$ and $\mathrm{B}_{21}$, respectively. But its CMC enzyme activity and cotton enzyme activity were lower than its single strain. The filter paper activities of the composite microbial system $\mathrm{FH} 2$ and FH4 were lower than those of their single strains. Compared with $\mathrm{F}_{13}, \mathrm{~B}_{16}$ and $\mathrm{B}_{21}$, the filter paper activity of $\mathrm{FH} 2$ decreased $45.3,26.7$ and $44.4 \%$, the CMC enzyme activity decreased 10.3 , 37.0 and $58.5 \%$, while the cotton enzyme activity was improved by $127.5,107.1$, and $78.5 \%$, respectively. The filter paper enzyme activity of FH4 decreased 49.2, 59.8, 46.0 and 59.1\%, the CMC enzyme activity was improved by 160.2 , $121.6,55.8$ and $2.5 \%$, while the cotton activity decreased 23.3, 54.9, 58.9 and $64.6 \%$ compared with $\mathrm{F}_{9}, \mathrm{~F}_{13}, \mathrm{~B}_{16}$ and $\mathrm{B}_{21}$, respectively.

Table 3 - Results of enzyme activities of composite microbial systems FH1-4.

\begin{tabular}{cccc}
\hline & & Cellulase activities & \\
\cline { 2 - 4 } CMS* Nos & CMC & Cotton \\
& filter paper $\left(\mathbf{U ~ g ~ g}^{-\mathbf{1}}\right)$ & $13.80 \pm 0.69$ & $0.21 \pm 0.01$ \\
FH1 & $11.13 \pm 0.56$ & $24.92 \pm 1.25$ & $1.16 \pm 0.06$ \\
FH2 & $5.38 \pm 0.27$ & $102.89 \pm 3.14$ & $0.75 \pm 0.04$ \\
FH3 & $21.34 \pm 1.07$ & $61.57 \pm 1.08$ & $0.23 \pm 0.02$ \\
FH4 & $3.96 \pm 0.20$ &
\end{tabular}

* CMS-Composite Microbial Systems

Among the four composite microbial systems, FH3 had the highest cellulose degradation ability. All the three enzyme activities got increased compared to that of three single strains. Being related to $F_{9}, B_{16}$ and $B_{21}$, the filter paper enzyme activity of FH3 were improved by 174.0, 190.7 and $120.5 \%$, the CMC enzyme activity were improved by 334.9, 160.3 and $71.3 \%$, and the cotton activity were improved by 150.0, 33.9 and
$15.4 \%$, respectively. Therefore FH3 was the best and used in further studies.

\section{Effects of culture temperature on the enzyme production of $\mathrm{FH3}$}

FH3 was inoculated in the PCS liquid medium and cultured for three days at different temperatures. The relationship between the relative enzyme activity and temperature is shown in Fig. 1. 


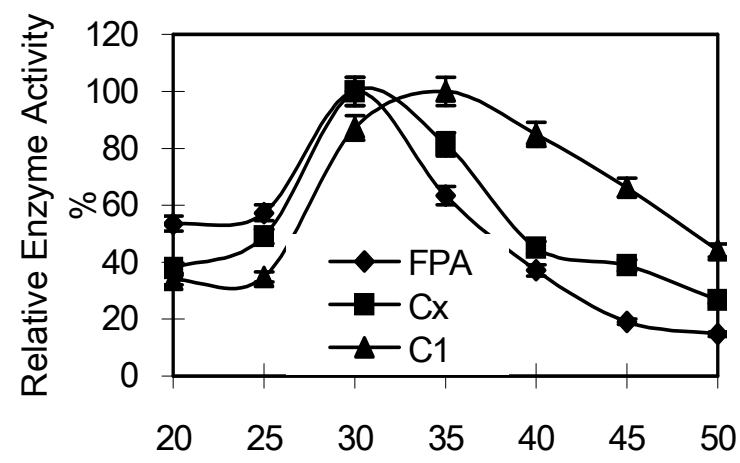

Figure 1 - Effects of culture temperature on the enzyme production of FH3 FPA-filter paper activity, $\mathrm{Cx}-\mathrm{CMC}$ activity, $\mathrm{C} 1$-cotton activity.

Temperature is one of the most important factors affecting microorganisms' growth (Andreaus et al., 1999; Tuomela et al., 2000). Fig. 1 indicated that the filter paper activity and CMC enzyme activity were greatly affected by the temperature and reached the maximum at $30{ }^{\circ} \mathrm{C}$ with a sharp peak. The cotton activity remained higher at 30 40 ${ }^{\circ} \mathrm{C}$ and reached the maximum at $35^{\circ} \mathrm{C}$.

\section{Effects of initial $\mathrm{pH}$ of medium on the enzyme production of $\mathrm{FH3}$}

Another important factor significantly affecting the cellulase production was the initial $\mathrm{pH}$ of the medium. In this study, the $\mathrm{FH} 3$ was inoculated in the PCS liquid medium and incubated at $30{ }^{\circ} \mathrm{C}$ for three days at different initial $\mathrm{pH}$. The relationship between the relative enzyme activity and initial $\mathrm{pH}$ is shown in Fig. 2.

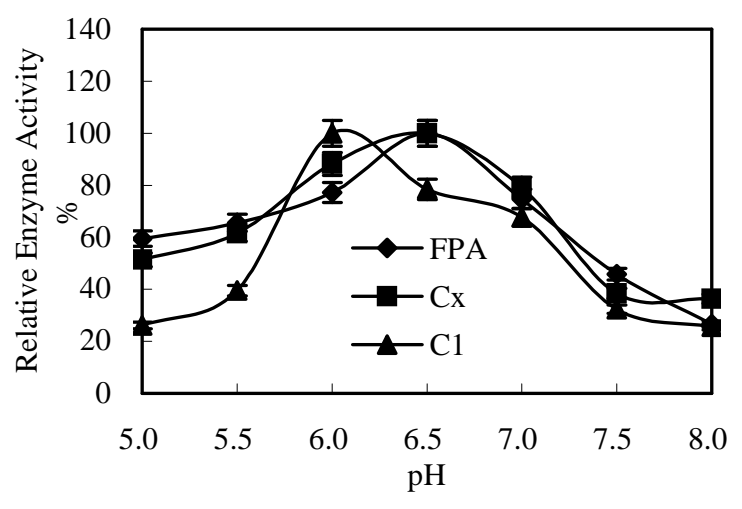

Figure 2 - Effects of initial pH value of medium on the enzyme production of FH3.

The initial $\mathrm{pH}$ of the medium showed a significant effect on the filter paper activity, CMC activity and cotton activity. When the initial $\mathrm{pH}$ value ranged from 5.5 to 7.5 , the three activities had a strong variation. The filter paper activity and CMC enzyme activity reached the maximum at $\mathrm{pH} 6.5$ and the cotton activity at $\mathrm{pH} 6.0$.

Effects of different carbon sources on the enzyme production of $\mathbf{F H 3}$

Cellulase is an inducible enzyme system (Kubicek, 1993; Kubicek et al., 1993; Ryu et al., 1980). All the microorganisms produced the highest level of cellulase when grew on cellulose (Stewart et al., 1976; Wood, 1985). Bran, filter paper, glucose, sucrose, bran + sucrose, filter paper + glucose, filter paper + sucrose were used as the carbon sources in the PCS liquid medium. The nitrogen source of medium was peptone. $\mathrm{FH} 3$ was inoculated in the medium and incubated at $30{ }^{\circ} \mathrm{C}$ and $\mathrm{pH} 6.0$ for three days. The relationship between the relative enzyme activity and carbon sources is shown in Fig. 3. 


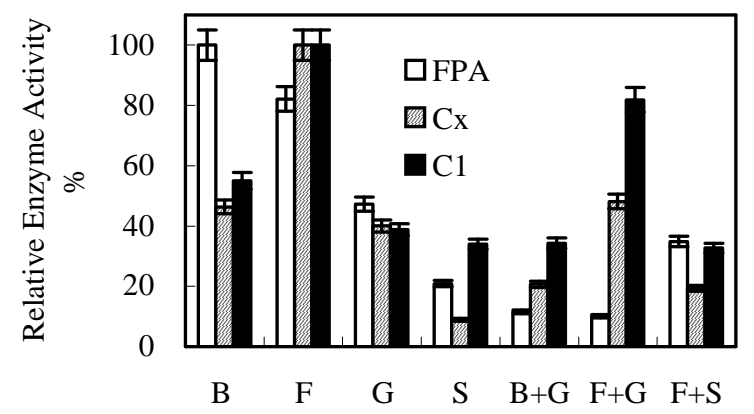

Figure 3 - Effects of carbon sources on the enzyme production of FH3 B-bran; F-filter paper; G-glucose; S- sucrose.

Evidently the filter paper activity reached the maximum value when the carbon source was bran. The three enzyme activities were higher with the filter paper as the carbon source, especially for the CMC activity and cotton activity, which reached the maximum value. Therefore, bran and filter paper were the favorable carbon sources, which could induce the FH3 to produce cellulase (Kvesitadze et al., 1999). The use of the soluble sugars can reduce certain problems during the large-scale fermentation. In this study, pure sugars gave good growth but cellulase production was very poor. This could be due to the fact that easily metabolizable substrates might prevent the enzyme synthesis (Seyis et al., 2005).

For further studies on the enzyme production by FH3, some small molecule carbon sources such as glucose and sucrose were added to the medium. Bran + sucrose, filter paper + glucose and filter paper + sucrose were used as the carbon sources in the PCS liquid medium. The results in Fig. 3 showed that the enzyme activity of $\mathrm{FH} 3$ decreased greatly because of glucose and sucrose. It was consistent with the inducible characteristics of the cellulase.

\section{Effects of different nitrogen sources on the enzyme production of $\mathrm{FH3}$}

FH3 was inoculated in the PCS liquid medium with different nitrogen sources and incubated at 30 ${ }^{\circ} \mathrm{C}, \mathrm{pH} 6.0$ for three days. The carbon source of medium was bran. The relationship between the relative enzyme activity and nitrogen sources is shown in Fig. 4.

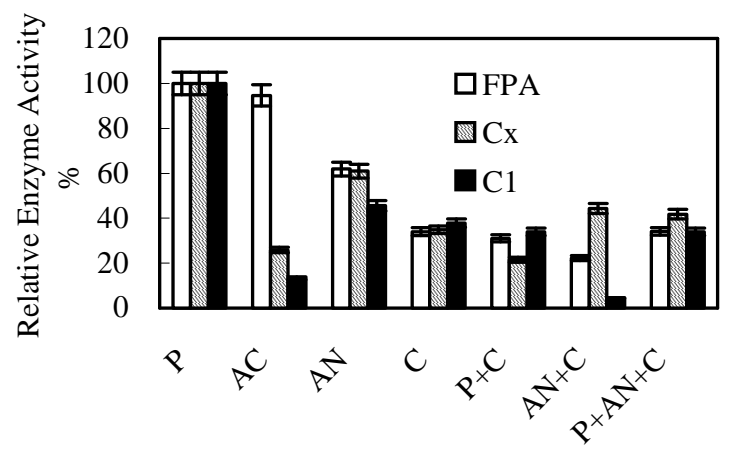

Figure 4 - Effects of nitrogen sources on the enzyme production of FH3 P-peptone; AC-ammonium citrate; $\mathrm{AN}$ - ammonium nitrate; $\mathrm{C}$-urea.

The nitrogen source used in the production medium is one of the major factors affecting the enzyme production and level. Fig. 4 indicated that FH3 had the highest enzyme activities when peptone was used as the sole nitrogen source. The results showed that organic nitrogen source restrained FH3 to produce cellulase. Urea as a nitrogen source is widely used in industry, but it didn't induce FH3 to produce the cellulase well in this study. In order to make use of urea, peptone + 
urea, ammonium nitrate + urea and peptone + ammonium nitrate + urea were used as the mixed nitrogen source for fermentation. The results showed that none of these were useful.

\section{Relationship between culture time and enzyme production of $\mathrm{FH3}$}

The composite microbial system of $\mathrm{FH} 3$ was inoculated in the most favorable medium at $30^{\circ} \mathrm{C}$ and $\mathrm{pH} 6.0$ for five days. The enzyme activities of the crude enzyme were measured at $12 \mathrm{~h}$ intervals. The variation of enzyme production with the culture time is shown in Fig. 5.

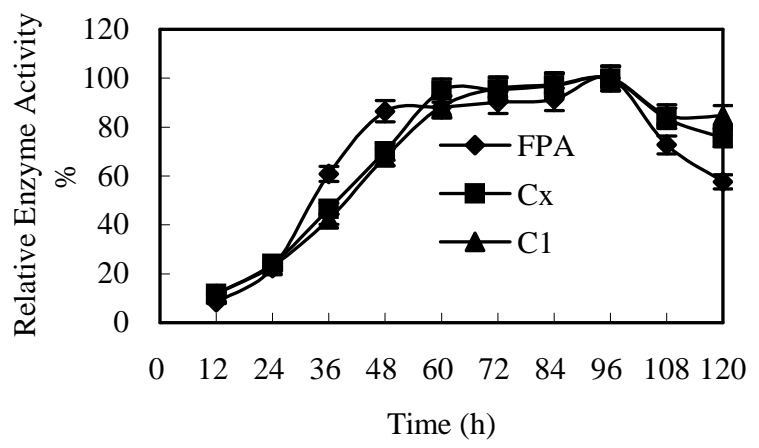

Figure 5 - Relationship between culture time and enzyme production of FH3.

The enzyme production by FH3 increased from $24 \mathrm{~h}$ to $48 \mathrm{~h}$ and kept constant during $48 \mathrm{~h}$ to $96 \mathrm{~h}$. After 96h, the enzyme activity decreased greatly. It might be concluded that the best culture time for FH3 was from 48 h to 96 h.

\section{Effects of temperature on the enzyme reaction of $\mathrm{FH} 3$}

The variation of the enzyme activity at different temperatures is shown in Fig. 6. Filter paper activity and cotton activity were at a high level when temperature was in the range of $45 \sim 55^{\circ} \mathrm{C}$, where they were all above $80 \%$. The relative enzyme activity of CMC was $63.38 \%$ at $45^{\circ} \mathrm{C}$ and it exceeded $80 \%$ at $50 \sim 60^{\circ} \mathrm{C}$. The highest activities of the three enzymes were at $50{ }^{\circ} \mathrm{C}$. It suggested that the best enzyme reaction temperature was 50 ${ }^{\circ} \mathrm{C}$. It could prove that $\mathrm{FH} 3$ had a very wide range of temperature, which was a very important parameter for the industry.

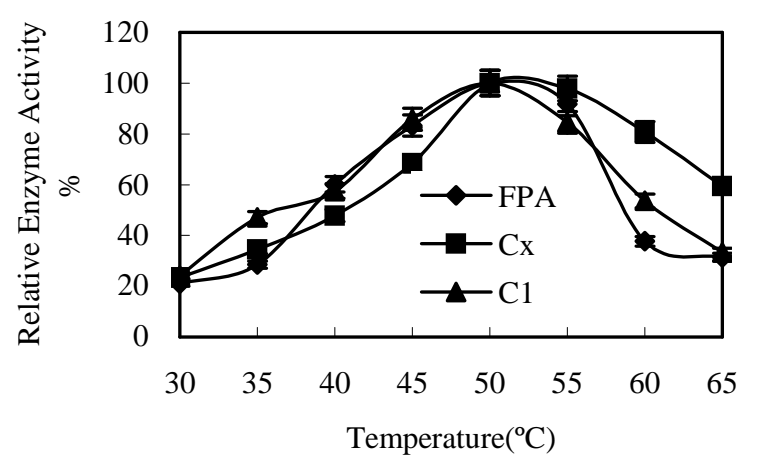

Figure 6 - Effects of temperature on the enzyme reaction of FH3.

\section{Effects of pH on the enzyme activity of FH3}

The variation of crude enzyme of $\mathrm{FH} 3$ at different $\mathrm{pH}(3.0,3.5,4.0,4.5,5.0,5.5,6.0$ and 6.5) is shown in Fig. 7.
Enzyme activity is markedly affected by $\mathrm{pH}$. This is because the substrate binding and catalysis are often dependent on the charge distribution on both, substrate and, in particular enzyme molecules 
(Shah et al., 2005). And the three kinds of enzyme activities of $\mathrm{FH} 3$ were very low under the highly acidic conditions, but they all increased slowly with the rise of $\mathrm{pH}$. Filter paper and cotton activities reached the highest value at $\mathrm{pH} 4.5$, and then they decreased slowly with the rise of $\mathrm{pH}$. The CMC activity reached the highest at $\mathrm{pH}$ 5.0. Fig. 7 indicated that the filter paper and cotton activities kept a high level at $\mathrm{pH} 4.0 \sim 5.5$, the range was wider than that of CMC activity which was at $\mathrm{pH}$ 4.5 5.5.

\section{Thermal stability of the crude enzyme of FH3}

The thermal stability is a very important aspect when considering the industrial application of the enzymes (Heck et al., 2005). The profiles of the thermal stability of cellulase at 30, 35, 40, 45, 50, 55, 60 and $65^{\circ} \mathrm{C}$ are represented in Fig. 8 .

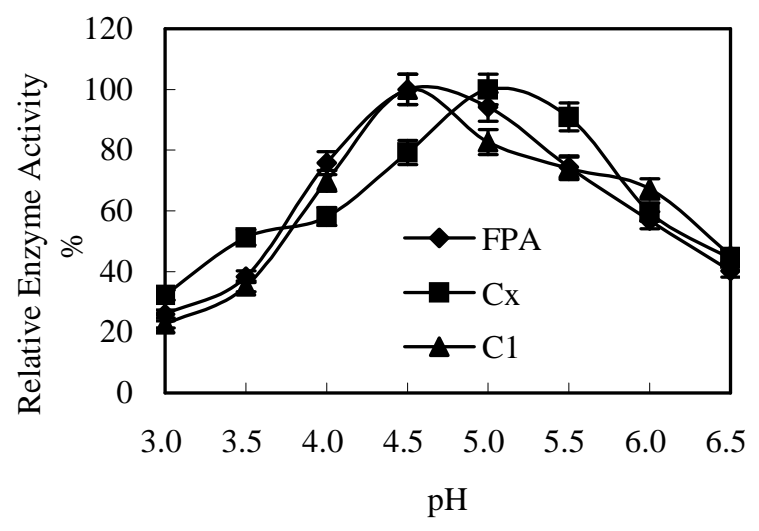

Figure 7 - Effects of pH on the enzyme activity of FH3.

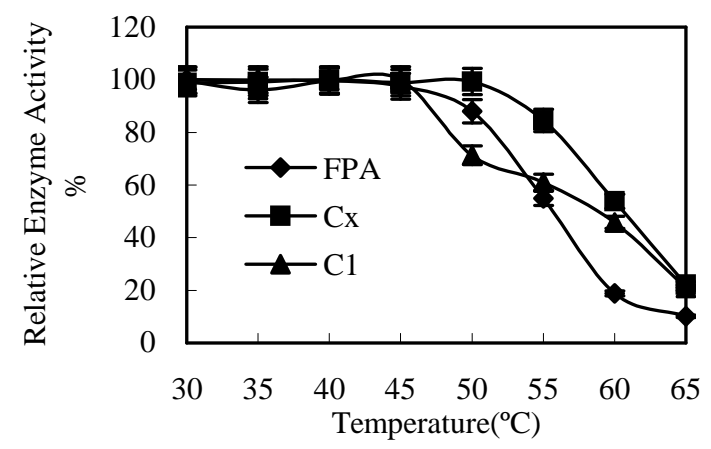

Figure 8 - The thermal stability crude enzyme of FH3.

The utilization of the enzymes in the industrial process often encounters the problem of the thermal inactivation of the enzyme. The thermal stability studies were carried out by preincubating the enzymes up to $3 \mathrm{~h}$ in the range of $30 \sim 65^{\circ} \mathrm{C}$. The CMC activity had a better thermal stability than the other two activities. The three kinds of enzyme activities were at a higher level at $30 \sim 45^{\circ} \mathrm{C}$, and then decreased sharply above $50^{\circ} \mathrm{C}$. When the temperature reached at $65^{\circ} \mathrm{C}$, the filter paper activity, $\mathrm{CMC}$ activity and cotton activity decreased $68.57,40.57$ and $66.62 \%$ respectively, compared to the highest enzyme activities. From Fig. 8, it could be concluded that the thermal stability temperature was around $60^{\circ} \mathrm{C}$.

\section{CONCLUSIONS}

The FH3 was a composite microbial system with a high yield of cellulase. Its enzyme activity increased nearly two-fold compared to single 
strain. The optimal enzyme production conditions of $\mathrm{FH} 3$ were as follows: initial $\mathrm{pH}$ 6.0 6.5, temperature $30 \sim 35^{\circ} \mathrm{C}$, shaker revolution $120 \sim 160$ rpm and culture time 48h 96h. The optimal carbon source was filter paper and bran, and the optimal nitrogen source was peptone. The optimal conditions for enzymatic activities were: temperature $45 \sim 55^{\circ} \mathrm{C}$ and $\mathrm{pH} 4.5 \sim 5.5$. The thermal stability temperature of $\mathrm{FH} 3$ was under $60^{\circ} \mathrm{C}$.

\section{ACKNOWLEDGEMENTS}

This work was supported by Shanxi Municipal Science and Technology Commission (No 030024).

\section{REFERENCES}

Andreaus, J.; Azevedo, H. and Cavaco-paulo, A. (1999), Effects of temperature on the cellulose binding ability of cellulase enzymes. Journal of Molecular Catalysis B: Enzymatic., 7, 233-239.

Carrard, G.; Koivula, A. and Soderlund, H. (2000), Cellulose-binding domains promote hydrolysis of different sites on crystalline cellulose. Proceedings of the National Academy of Sciences of the United States of America., 97, 10342-10347.

Garsoux G.; Lamotte, J. and Gerday, C. (2004), Kinetic and structural optimisation to catalysis at low temperatures in a psychrophilic cellulase from the Antarctic bacterium Pseudoalteromonas haloplanktis. Biochemical Journal., 384, 247-253.

Haruta, S.; Cui, Z. and Huang, Z. (2002), Construction of a stable microbial community with high cellulosedegradation ability. Applied Microbiology and Biotechnology., 59, 529-534.

Heck, J. X.; Flores, S. H. and Hertz, P. F. (2005), Optimization of cellulase-free xylanase activity produced by Bacillus coagulans BL69 in solid-station cultivation. Process Biochemistry., 40, 107-112.

Kim, S. W.; Kang, S. W. and Lee, J. S. (1997), Cellulase and xylanase production by Aspergillus Niger KKS various bioreactors. Bioresource Technology., 59, 63-67.

Kubicek, C. P. (1992), The cellulase proteins of T. reesei: structure,multiplicity, mode of action and regulation of formation. Advances in Biochemical Engineering and Biotechnology., 45, 1-27.
Kubicek, C. P.; Messner, R. and Gruber, F. (1993), The Trichoderma reesei cellulase regulatory puzzle: From the interior life of a secretory fungus. Enzyme and Microbial Technology., 15, 90-99.

Kvesitadze, E.; Adeishvili, E. and Gomarteli, M. (1999), Cellulase and xylanase activity of fungi in a collection isolated from the southern Caucasus. International Biodeterioration and Biodegradation., 43, 189-196.

Li, Z. H. and Lu, Y. T.(2003), Screening on the cellulose-decomposing microorganisms. Environment Pollution and Control., 23, 133-135

Mandels, M. (1985), Applications of cellulases. Biochemical society transactions., 13, 414-416

Miller, G. L. (1959), Use of dinitrosalicilic acid reagent for determination of reducing sugar. Analatical. Chemistry., 31, 426-428.

Peter, M.; Zarnea, G. and Adrian, P. (1999), Biodegradation and bioconversion of cellulose wastes using bacterial and fungal cells immobilized in radiopolymerized hydrogels. Resources Conservation and Recycling., 27, 309-332.

Seyis, I. and Aksoz, N. (2005), Effect of carbon and nitrogen sources on xylanase production by Trichoderma harzianum 1073 D3. International Biodeterioration and Biodegradation, 55, 115-119.

Shah, A. R. and Madamwar, D. (2005), Xylanase production by a newly isolated Aspergillus foetidus strain and its characterization. Process Biochemistry., 40, 1763-1771.

Shoham, Y.; Lamed, R. and Bayer, E. A. (1999), The

cellulosome concept as an efficient microbial strategy for the degradation of insoluble polysaccharides. Trends in Microbiology., 7, 275-281.

Stewart, B. J. and Leatherwood, J. M. (1976), Depressed synthesis of cellulase by Cellulomonas. Journal of Bacteriology., 128, 609-615.

Tuomela, M.; Vikman, M. and Hatakka, A. (2000), Biodegradation of lignin in a compost environment: a review. Bioresource Technology., 72, 169-183.

Van Wyk, J. P. H. and Mohulatsi, M. (2003), Biodegradation of wastepaper by cellulase from Trichoderma Viride. Bioresource Technology., 86, 21-23.

Wood, T. M. (1985), Properties of cellulolytic enzyme systems. Biochemical Society Transactions., 13, 407410.

Received: January 05, 2006; Revised: November 26, 2007; Accepted: June 10, 20078. 